\title{
REDUCING STIGMA, DEPRESSION AND ANXIETY IN PEOPLE WITH HIV THROUGH A COGNITIVE BEHAVIORAL THERAPY GROUP
}

\author{
David Biel Soro ${ }^{1,2}$, José Antonio Carrobles ${ }^{1}$ and María Antón García \\ ${ }^{1}$ Autonomus University of Madrid; 'ªbc psicología (Spain)
}

\begin{abstract}
A number of people with HIV participated in a 48-hour cognitive behavioral group intervention, divided into four monthly workshops. Twenty-six participants started the program and 18 completed it and responded at the four-month followup. After treatment, significant improvement was achieved in declared stigma, internalized stigma, depression and state anxiety. All these improvements were maintained at the follow-up measurement four months later, with trait anxiety also improving in this last measure. Participants' results were compared with an HIV control group. Twenty-four respondents completed the first test battery and 16 completed the last. The evolution of this group was assessed, as well as the differences between both groups at three time points: pre-intervention, postintervention and follow-up. Intragroup and inter-group comparisons were examined with the Student $t$-tests for related samples and for independent samples respectively. In addition, the effect size was calculated for each comparison. The results support the efficacy of the group intervention presented.

KEY WORDS: HIV, stigma, depression, anxiety, group treatment.
\end{abstract}

\section{Resumen}

Un grupo de personas con VIH participaron en una intervención grupal, de base cognitivo conductual de 48 horas, dividida en cuatro talleres, uno cada mes (26 iniciaron el programa y 18 lo terminaron y contestaron en el seguimiento cuatro meses después). Tras el tratamiento se consiguieron mejorías significativas en estigma declarado, estigma interiorizado, depresión y ansiedad estado. Todas estas mejorías se mantuvieron en la medición de seguimiento cuatro meses después, mejorando en esta última medida también la ansiedad rasgo. Se compararon sus resultados con un grupo de control de personas con VIH (24 contestaron a la primera batería de test y 16 a la última). Se evaluó la evolución de este grupo, así como las diferencias entre ambos grupos para cada momento: preintervención, posintervención y seguimiento. Las comparaciones intragrupales e intergrupos se evaluaron con las pruebas $t$ de Student para muestras relacionadas y para muestras independientes respectivamente. Además, se calculó el tamaño de efecto para cada comparación. Los resultados avalan la eficacia de la intervención grupal presentada.

PALABRAS CLAVE: VIH, estigma, depresión, ansiedad, terapia grupal.

Correspondence: David Biel Soro, abc psicología, c/ Coso 98-100, 8², 50001 Zaragoza (Spain). Email: david@abcpsicologia.info 


\section{Introduction}

The existence of different forms of discrimination against people with human immunodeficiency virus (HIV) is a fact that has been confirmed worldwide (ONUSIDA, 2005; UNAIDS, 2014a,b; UNAIDS, 2017) and also in Spain (Aguirrezabal, Fuster, \& Valencia, 2009; ALTER, 2014; Fuster et al., 2010; Fuster-RuizdeApodaca, Benito, Poveda, Rohlfs, \& Sanpedro, 2018; Laparra et al., 2014; Ramiro \& Ramírez, 2016). As a socially stigmatized health condition, people with HIV also suffer the consequences of stigma and discrimination on their health (Grossman \& Stangl, 2013; Hatzenbuehler, Phelan, \& Link, 2013; Logie \& Gadalla, 2009; Stockton, Giger, \& Nyblade, 2018; Vanable, Carey, Blair, \& Littlewood, 2006). This includes higher rates of stress (Carrobles, Remor, \& Rodríguez-Alzamora, 2003; Stutterheim et al., 2009), anxiety and depression (Edo \& Ballerster, 2006; Gaviria, Quiceno, Vinaccia, Martínez, \& Otalvaro, 2009; Rabkin, 2008; Tesfaw et al., 2016) than the general population.

Advances in HIV research and treatment led, 16 years after its first report in the weekly reports of the U.S. Centers for Disease Control and Prevention (CDC, 1981), to the use of the highly active anti-retroviral therapy (HAART). Thanks to HAART, and its spread to many parts of the world, HIV is now a chronic infection with a decreasing negative impact on the health of those infected. It is true that there is some comorbidity associated with HIV (Petoumenos et al., 2017) even when it is well treated, such as some neoplasms, or some degree of premature aging. However, the life expectancy and quality of life of people with HIV with good adherence to antiretroviral treatment and healthy living habits is almost equal to that of the general population (Gueler et al., 2017).

As regularly reported by the CDC (2020), the transmissibility of HIV is significantly lower than that of other infections (Boily et al., 2009; Fox et al., 2011). Moreover, with undetectable viral load, which is achieved in most cases with good treatment adherence, we can now say that undetectable is untransmissible. This means that persons with viral load below 50 copies per ml. of blood do not transmit the virus in their unprotected (without condom) sex relations, nor to their unborn children. And we can affirm this thanks to studies such as the PARTNER (Rodger et al., 2012; Rodger et al., 2016; Rodger et al., 2018; Rodger et al., 2019), which have studied thousands of serodiscordant couples who had tens of thousands of unprotected sexual relations over the years without any transmission related to such sexual practices or to vertical transmission (mother-to-child) being discovered.

It therefore appears that medical research and treatment are stopping, rather than eliminating, the harmful health consequences of HIV, except for the stigma and discrimination, which are still present, as we have seen. It is not the HIV infection itself that causes depression and anxiety, but the climate of rejection, prejudice and discrimination that these people suffer (Espada et al., 2013; Fuster-RuizdeApodaca et al., 2018; Logie \& Gadalla, 2009; Stutterheim et al., 2009). It is therefore not surprising that many efforts have been made to find psychological interventions to help these individuals to reduce the impact of stigma on their emotional well-being (Feyissa, Lockwood, Woldie, \& Munn, 2018; Fuster-RuizdeApodaca et al., 2016; Gaviria et al., 2009; Jalali, Hashemi, \& Hasani, 2018; Ma, Chan, \& Loke, 2019; 
Stangl, Lloyd, Brady, Holland, \& Baral, 2013). The passage of time itself is known to be a positive influential factor in the emotional well-being of people with HIV (Elias, Mendes, \& Mello, 2012), and some psychological interventions are known to help to reduce the time it takes them to feel better. Over the past decade there has been an exponential increase in studies of group-based treatments to reduce stigma, depression and anxiety in people with HIV (Edo \& Ballester, 2006; Honagodu, Krishna, Sundarachar, \& Lepping, 2013; Jayasvasti et al., 2011; Rueda et al., 2016). Many of them have proved effective, although sustainability over time of the positive effects of the interventions has rarely been tested. Those of us who work with people with HIV observe that the psychological interventions with the most lasting impact are those that are prolonged over time rather than carried out briefly only once (Mak, Mo, Ma, \& Lam, 2017).

This study presents a group-based cognitive behavioral intervention with information on HIV and stigma, training in improving self-esteem, communication skills, and emotional management. Outcomes on stigma, depression and anxiety are assessed and compared to a group of people with HIV who do not participate in the therapeutic intervention before treatment, at the end of treatment and four months after completion.

In order to carry out this study, the mandatory favourable report was obtained from the Research Ethics Committee of the Autonomous University of Madrid.

\section{Method}

\section{Participants}

Fifty people with HIV from the Autonomous Community of Aragon were invited to participate in this study. They were offered the possibility of being in the waiting list/control group or in the cognitive behavioral therapy group. Out of the total, 26 people went to the therapy group and the other 24 to the control group. Out of these, 36 people -18 in each group - completed the first phase of treatment or waiting time, as appropriate. The follow-up questionnaires were completed 4 months after the end of treatment: 18 for the treatment group and 16 for the waiting list group.

Table 1 shows the socio-demographic data for both groups. These data are very similar to those provided by Rodríguez, Barreales and Tuesta (2018). And, if we take into account the tendency of participants with more recent diagnoses to join the therapy group rather than the control group, we see that the sociodemographic differences found between the groups are in line with the data of the National Register of New HIV Diagnoses in Spain (Ministerio de Salud, Consumo y Bienestar Social, 2018). 
Table 1

Sociodemographic data and $c h{ }^{2}$ comparison for differences between groups

\begin{tabular}{|c|c|c|c|c|}
\hline Variables & $\begin{array}{l}\text { Therapy } \\
\text { group }\end{array}$ & $\begin{array}{l}\text { Control } \\
\text { group }\end{array}$ & Total & $\chi^{2}$ \\
\hline Sex & & & & $0.031(p=.860)$ \\
\hline Man & 19 & 17 & 36 & \\
\hline Woman & 7 & 7 & 14 & \\
\hline Transsexual & 0 & 0 & 0 & \\
\hline Age & & & & $9.458(p=.092)$ \\
\hline Under 20 years & 0 & 1 & 1 & \\
\hline From 20 to 30 years & 4 & 0 & 4 & \\
\hline From 31 to 40 years & 5 & 1 & 6 & \\
\hline From 41 to 50 years & 9 & 10 & 19 & \\
\hline From 51 to 60 years & 7 & 11 & 18 & \\
\hline Over 60 years & 1 & 1 & 2 & \\
\hline Educational level & & & & $0.435(p=.805)$ \\
\hline Primary education & 6 & 7 & 13 & \\
\hline High school & 14 & 13 & 27 & \\
\hline University degree & 6 & 4 & 10 & \\
\hline Sexual orientation & & & & $4.226(p=.238)$ \\
\hline Heterosexual & 13 & 18 & 31 & \\
\hline Homosexual & 8 & 5 & 13 & \\
\hline Bisexual & 4 & 1 & 5 & \\
\hline $\mathrm{Ns} / \mathrm{Nc}$ & 1 & 0 & 1 & \\
\hline Year of diagnosis & & & & $3.887(p=.274)$ \\
\hline Before 1990 & 3 & 4 & 7 & \\
\hline Before 1997 & 3 & 6 & 9 & \\
\hline Before 2010 & 11 & 12 & 23 & \\
\hline Since 2010 & 9 & 2 & 11 & \\
\hline Years since diagnosis & & & & $5.024 *(p=.025)$ \\
\hline Less than 3 years & 9 & 2 & 11 & \\
\hline More than 3 years & 17 & 22 & 39 & \\
\hline Way of transmission & & & & $5.127(p=.275)$ \\
\hline Sexual relationship & 17 & 10 & 27 & \\
\hline Intravenous & 3 & 8 & 11 & \\
\hline Transfusion & 1 & 0 & 1 & \\
\hline Vertical & 1 & 1 & 2 & \\
\hline $\mathrm{Ns} / \mathrm{Nc}$ & 4 & 5 & 9 & \\
\hline Employment status & & & & $2.520(p=.284)$ \\
\hline Work with contract & 11 & 6 & $34.0 \%$ & \\
\hline Work without a contract & 0 & 1 & $2.0 \%$ & \\
\hline Doesn't work & 15 & 17 & $64.0 \%$ & \\
\hline Receives welfare benefit & & & & $0.297(p=.586)$ \\
\hline Yes & 11 & 12 & 23 & \\
\hline No & 15 & 12 & 27 & \\
\hline
\end{tabular}

Note: ${ }^{*} p<.05$. 


\section{Instruments}

a) A scale of stigma associated with HIV and AIDS. This scale was extracted from the battery of psychosocial predictors of quality of life by Remor et al. (2012) and validated in subsequent studies (Fuster-RuizdeApodaca, Molero, Biel, \& Barranco, 2013 and Fuster-RuizdeApodaca, Molero, \& Ubillos, 2016). It had a $10 \mathrm{~cm}$ analogical visual response format. The scale was composed of 10 items: four for declared stigma and six for internalized stigma. The declared stigma refers to a person's perception of the rejection he/she suffers, both directly because he/she has HIV, and from the perception of discrimination against people with HIV in society (e.g., "I personally feel rejected for having HIV", "In society there is rejection of people with HIV"). Internalized stigma refers to a person's assumption of discriminatory and stigmatizing beliefs, feelings and attitudes in society (e.g., "I don't think anyone will love me anymore because I have HIV", "I prefer to avoid having sex so as not to reveal that I have HIV" or "Having HIV makes me feel inferior to other people"). The internal consistency found in the previous studies in which it has been used (Fuster-RuizdeApodaca et al., 2013, Fuster-RuizdeApodaca, Molero, \& Ubillos, 2016) was between $\alpha=$ .46 and $\alpha=.63$ for the declared stigma. In this study $\alpha=.39$ in the pre, $\alpha=.47$ in the post, and $\alpha=.40$ in the follow up. For the internalized stigma in the previous studies (opus cit.) it was between $\alpha=.79$ and $\alpha=.84$. In the current sample $\alpha=.73$ in the pre, $\alpha=.76$ in the post, and $\alpha=.73$ in the follow up.

b) Beck Depression Inventory-II (BDI-II; Beck, Steer, \& Brown, 2011). The BDI-II is composed of 21 items with four response options. This provides a fairly standardized indicator of the levels of depression during the past two weeks, which meets the criteria of the Diagnostic and statistical manual of mental disorders-fifth edition (DSM-5) and the World Health Organization's 10th International statistical classification of diseases and related health problems (ICD-10). It is also the fifth most-used test by psychologists in Spain (Muñiz \& Fernández-Hermida, 2010). The internal consistency reliability of the inventory gives an $\alpha=.87$ (Sanz, Perdigón, \& Vázquez, 2003). This study resulted in each of the three measurement times $\alpha=.88, \alpha=.90$ and $\alpha=.90$ respectively.

c) State-Trait Anxiety Inventory (STAl; Spielberger, Gorsuch \& Lushene, 1982). The STAI was chosen to measure anxiety because of its proven solvency, wide dissemination, use in different studies, and to provide differentiated measures of anxiety as a current state and anxiety as a stable personality trait. A brief onetime intervention may well reduce state anxiety. A reduction of trait anxiety should require a more profound therapeutic intervention (Carrasco, 1999; Linares-Ortiz, Robles-Ortega, \& Peralta-Ramirez, 2014) and an evaluation time after such intervention, as is the case of the present study. As for internal consistency, values of between .90 and .93 for state anxiety and between .84 and .87 for trait anxiety were found on $\alpha$ (Spielberger, Gorsuch, \& Lushene, 1982). With the present sample, $\alpha$ values were obtained for anxiety state of .93 in the first measurement, .92 after treatment and .96 in the follow-up. Trait anxiety on the other hand scored at $\alpha$ with .90, .92 and .93 respectively. 


\section{Procedure}

It is a quasi-experimental study with a non-equivalent control group and nonrandom assignment of participants to groups. Each participant freely chose whether to participate, and in which group. Thus, we reproduce the same conditions as in real care for people with HIV, where it is they who decide which therapeutic activities to participate in, if any.

The Research Ethics Committee, of the Autonomus University of Madrid evaluated and approved the research.

The selection of participants, as well as the organization and logistic work, was centralized in the Association for the support of people with HIV and Aids (Asociación para la ayuda a personas con VIH y sida), Omsida, in Aragon. The recruitment of participants was done through appeals to users of Omsida, as well as other associations linked to work with people with HIV and the health services of Zaragoza, specifically the infectious disease units. The various calls and selection interviews with potential participants were conducted over several months. In these interviews, they were informed of the objectives and procedures of the present study so that they could voluntarily decide whether they wished to participate in the study. Participants in the control group/waiting list were informed that after answering the three test batteries they could participate in the therapy group, if they wished. Some did so during the second year.

All participants completed a participation commitment document and an informed consent document at the same time as they completed the first set of questionnaires (pre-intervention). For the people in the control group it was administered in Omsida's premises, with the direct supervision of the co-therapist of the therapeutic group. For those in the therapeutic group it was at the Centro Joaquín Roncal of the Fundación CAI-ASC at the beginning of the first of the group's four workshops.

The therapy group held four 12-hour workshops over a weekend once a month. It was conducted by a psychologist, expert in psychological treatment of people with HIV, and another psychologist as co-therapist. An extended description of this intervention is shown below. At the end of the last workshop, the battery of questionnaires was applied again (post-intervention). For the control group, a lapse of between four and six months was established, depending on their availability, from the time they responded to the first battery to fill a second measurement. Both groups were given the battery again four months after the second one (follow-up).

All of the above was repeated exactly the same a second year to expand the number of participants in both groups.

\section{DESCRIPTION OF THE INTERVENTION}

The intervention program of the cognitive behavioral based therapeutic group emerged from the studies of Fuster (Biel, 2011; Fuster, 2011; Fuster-RuizdeApodaca, Molero, Biel, \& Barranco, 2013; Fuster-RuizdeApodaca, Molero, \& Ubillos, 2016): A 16-hour in a weekend group intervention with good results in reducing stigma, 
improving self-esteem and perceived self-efficacy, increasing primary and secondary coping skills and quality of life.

The intervention program used in this study was divided into four 12-hour workshops held at weekends, at a rate of one per month. Each workshop had three four-hour sessions. A detailed description of the content of the 4 workshops can be seen in the Appendix. In the first workshop, emphasis was placed on stigma and discrimination. In addition, work on self-esteem, communication skills and emotional self-control was introduced. In the second and third workshops, the work was divided into self-esteem in the first session, communication skills in the second and emotional self-control skills in the third. In the fourth workshop we continued with the work on self-esteem, communication skills and emotional self-control and expanded the content with anti-discrimination rights and conflict resolution. Between workshops, homework was requested in line with the contents discussed. The beginning of each workshop consisted of a review of these tasks and the experiences of the participants during the past month.

\section{Data analysis}

For the data analysis, the statistical program for social sciences SPSS for Windows v. 22.0 was used. Given the non-random way of assigning participants to groups, the number of participants in each group and the differences observed in the sociodemographic variables, we proceeded to use normality tests to evaluate the suitability of using parametric tests for the comparison of the dependent variables. Kolmogorov-Smirnov test with Lillefors correction of significance was applied. When the variable did not pass the normality test, it was transformed into a logarithmic variable and reassessed. In all cases it was possible to use parametric tests. The significance level was set at $<.05$.

Intra-group comparisons were made for the dependent variables between each of the three measurement moments through the Student $t$-test for related samples. The effect size was also calculated with Cohen's $d$ statistical with technical support from Microsoft Windows' Excel program.

Finally, comparisons were made between the two groups at each of the three measurement points using the Student $t$-test for independent samples and the effect size was calculated for the differences between the groups.

\section{Results}

Tables 2 and 3 show the comparisons of means and effect sizes of the therapy group and the control group, respectively, at each of the three measurement points. Table 4 shows the mean and effect size comparisons between the therapy and control groups for each of the three measurement points. 


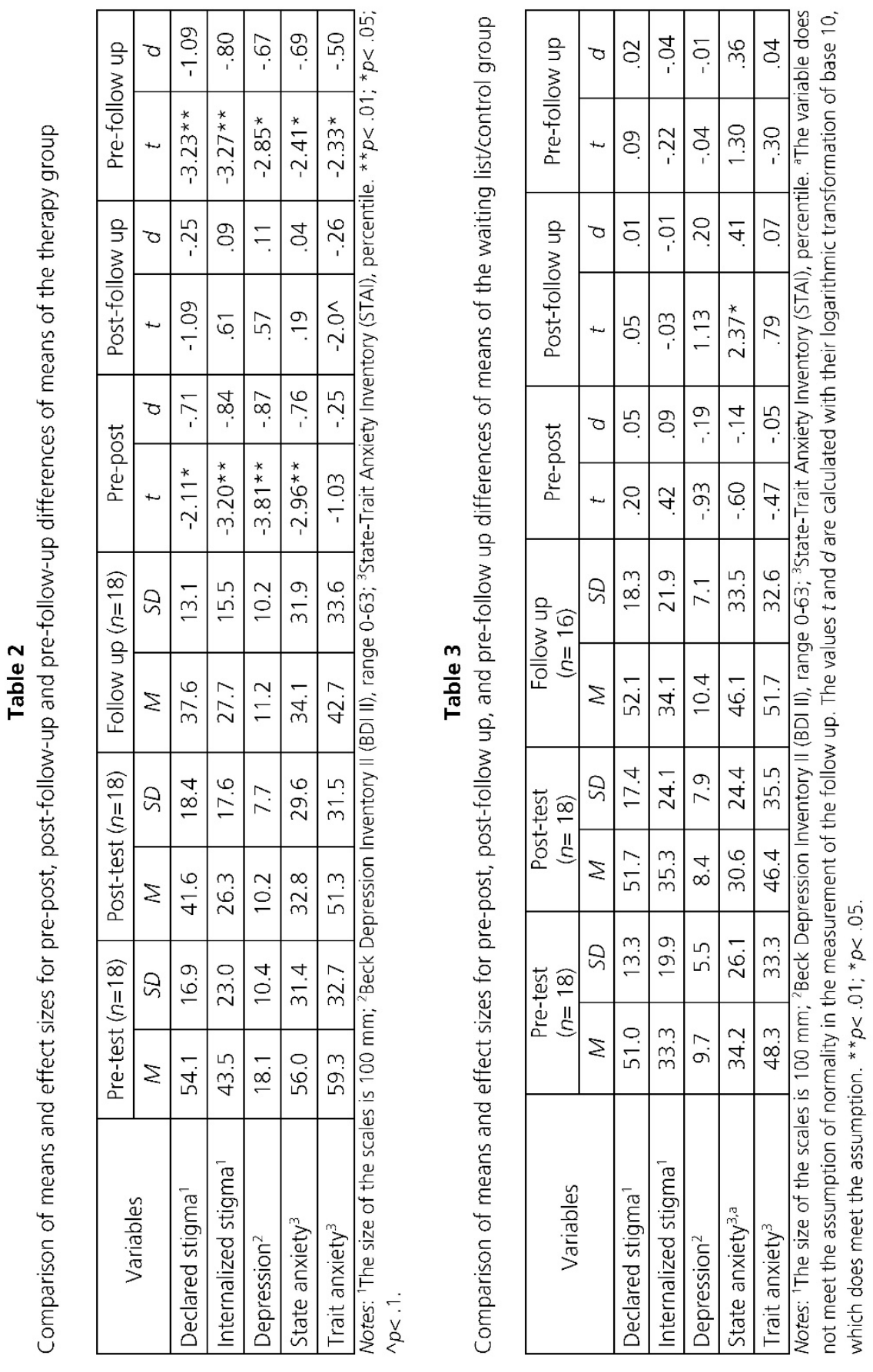




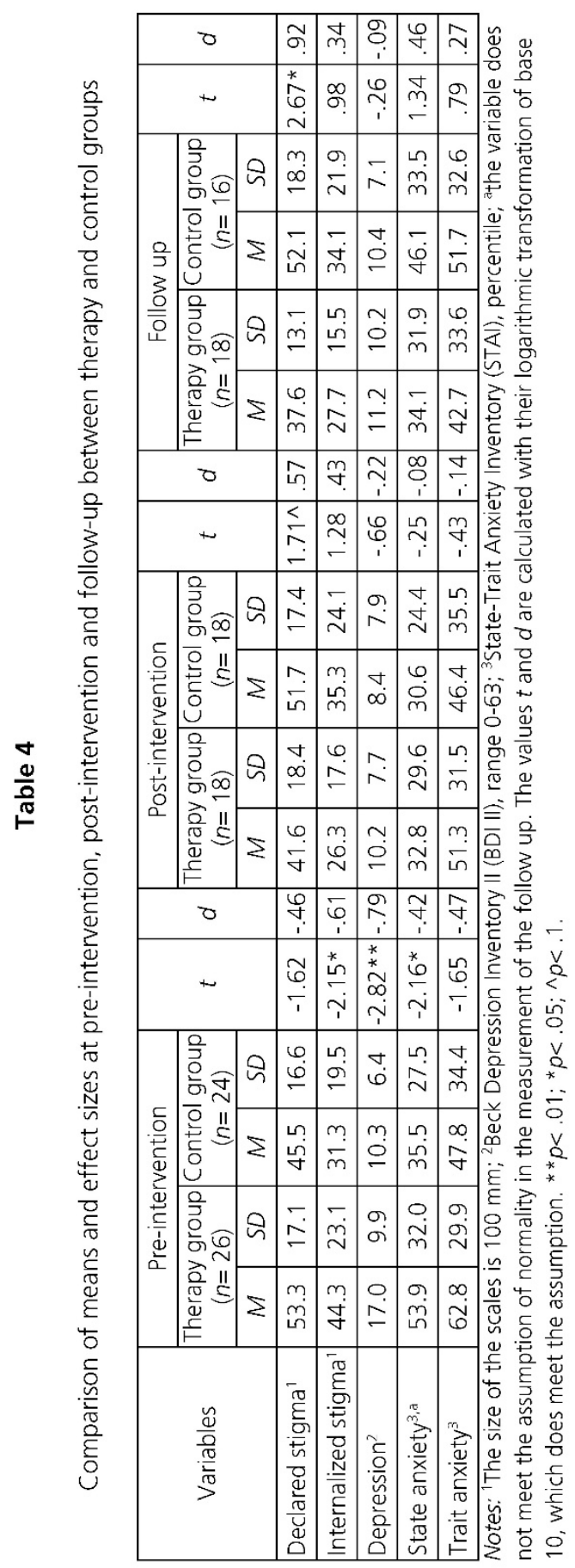




\section{Declared stigma}

Declared stigma decreased significantly in the therapy group at the end of treatment $(p=.050)$. With a medium-high effect size. It continued to do so in a nonsignificant way in the follow-up until it resulted in a significant reduction between the first and the third measurement $(p=.005)$ with a large effect size.

Within the waiting list group, no change was found between any of the measures of declared stigma and the effect size between all of them was almost zero. The declared stigma in this group remained stable throughout the research.

In the first measurement, the declared stigma of the therapy group appeared to be greater than that of the control group, but no significant difference was found $(p=.111)$. The scores of both groups were reversed after the treatment period, although again the differences did not meet the established criteria of significance $(p=$.097). Only in the follow-up measurement were the groups found to be different $(p=.011)$. At the beginning of the research the effect size is medium in favour of the control group. After the treatment it becomes middle in favour of the therapy group and big in the follow-up. Therefore, the reductions shown by the treatment group in each of the measurements, especially in the first period, and the stability found in the waiting list group, ended up giving significant differences in the last measurement.

\section{Internalized stigma}

Within the therapy group, internalized stigma decreased significantly at the end of treatment $(p=.005)$, maintaining the same level of significance of reduction at follow-up. The effect sizes were large, both between the first and second measurements and between the first and third measurements.

Within the waiting list group we found no change between the internalized stigma measures in any of the three measures, with virtually no effect sizes in each comparison. The internalized stigma in the control group remained stable.

Before treatment between groups, internalized stigma was significantly higher in the therapy group $(p=.037)$ with a medium effect size. At the end of the treatment and at the follow-up, the therapy group scored below the control group without significant differences ( $p=.210$ and $p=.333$, respectively). The effect size was also medium, although this time reversed in favour of the therapy group. Therefore, the worst results in internalized stigma of the therapy group before starting treatment were statistically matched after treatment and remained so at follow-up.

\section{Depression}

Depression clearly decreased in the therapy group at the end of treatment $(p=$ $.001)$ with a large effect size and remained reduced at follow-up ( $p=.011)$ with a medium effect size.

In the control group no change was found between the three depression measurements. The effect size is negatively small between the first and second 
measurement, positively small between the second and third measurement and zero between the first and third measurement. The depression in the control group remained stable.

In the first measurement depression was significantly higher in the therapy group ( $p=.007)$. At the end of the treatment both groups are equal $(p=.511)$. In the follow-up, they maintain the same level $(p=.797)$. Therefore, the higher depression ratings of the therapy group before treatment were statistically equal to those of the control group after treatment, and remained so at follow-up. As could be seen with the effect sizes, which were large before treatment, small after treatment and very small at follow-up.

\section{State anxiety}

In the therapy group significant reductions were observed between pre- and post-treatment state anxiety $(p=.009)$. Virtually no difference between end of treatment and follow-up $(p=.852)$. Between the first and third measurement the positive change is maintained $(p=.028)$. The effect size shows a medium to large reduction between before and after treatment and a medium to large effect between the first and third.

Within the control group the state anxiety variable did not pass the Kolmogorov-Smirnov test at the follow-up. Therefore, a logarithmic transformation was carried out, which did allow comparisons to be made with parametric tests. State anxiety remained stable during the treatment period $(p=.553)$, with a small effect size, after which it increased $(p=.032)$, with a medium effect size at followup. Although the pre-intervention follow-up differences were not significant ( $p=$ .212) and the effect size was medium.

In the comparison between groups, the scores of the therapy group were significantly higher in pre-treatment anxiety $(p=.035)$. They were statistically matched after treatment $(p=.807)$ and remained so at follow-up $(p=.191)$. The effect size is medium in favour of the control group before treatment, small after treatment, and medium in favour of the therapy group at follow-up.

\section{Trait anxiety}

Within the therapy group, trait anxiety decreased moderately and not significantly, with medium-small effect sizes, both after the intervention $(p=.317)$, and between the end of the intervention and follow-up ( $p=.062$ ). When comparing pre-treatment and follow-up results, a significant reduction $(p=.032)$ and a medium effect size do appear.

Within the control group, the trait anxiety variable showed no change between measurements, and the effect size was negligible between each measurement.

In the first measurement, trait anxiety was higher in the therapy group without reaching a statistically significant difference $(p=.105)$, and with a medium effect size. At the end of the treatment both groups were equal $(p=.669)$, with a small effect size. In the follow-up, they remained equal $(p=.434)$, with a medium-low effect size, but this time inverted in favour of the therapy group. 


\section{Discussion}

The results show that the control group maintains stability in the scores on most variables, or some variations that this study cannot explain, such as increased state anxiety in the follow-up period. Considering the small number of participants, it could be assumed that factors not controlled or analysed in this study, such as important life events in some of the participants, could have influenced such variations.

The therapy group showed a constant and unequivocal positive evolution in all the variables analysed. During treatment the declared stigma, internalized stigma, depression and state anxiety improved. All variables maintained the improvements at follow-up, even improved more, as in the cases of declared stigma or trait anxiety.

Trait anxiety, as measured by STAI, is the dependent variable most equivalent to a personality trait, and as such, resistant to change and stable over time. It had been proven before that these types of traits could be improved with long term individual or group therapy (Carrasco, 1999; Linares-Ortiz, Robles-Ortega, \& PeraltaRamirez, 2014). Once again, this possibility is suggested.

When comparing both groups, it is confirmed that those who decided to participate in the therapy group had worse rates in many of the variables evaluated. In other words, as is the case in reality, people who are relatively well do not make the effort to participate in a therapy group. Prior to the intervention, people in the therapy group scored worse on all variables, significantly worse on internalized stigma, depression and state anxiety.

It is known, though little has been published about it, that after the usual emotional downturn following an HIV diagnosis, the passage of time helps to improve emotional well-being. Elias, Mendes, and Mello (2012) found worse levels in all WHOQOL-120 HIV domains in people with less time since HIV diagnosis. Suárez, Peñate and Crespo (2009), found worse records in emotional intelligence in newly diagnosed people than in others with a diagnosis of more than one year. This study confirms that people who chose the treatment group, and who were worse off on all variables, had significantly more recent dates of diagnosis than those who chose not to participate in the treatment group. See, for example, the means and standard deviations of the control group (Table 4) in the BDI II. They are practically the same as those found in the general Spanish population in the study by Sanz, Perdigón and Vázquez (2003): n 470, M 9.4, SD 7.7. Compared to these measures, those displayed by the therapy group (Table 5 ) before the intervention were clearly superior ( $p=.007)$. These data would support the idea, perceived by those of us who work with people with HIV, that the passage of time after diagnosis tends to have a positive impact on their emotional well-being. More research on this would be of interest.

After treatment all variables were equal between both groups. At follow-up, the improvement in variables observed in the treatment group reaches levels of significance with respect to the control group in declared stigma, which had not initially been significantly different between the groups.

The effect sizes within the therapy group show medium to large changes. Within the control group small, insignificant or difficult to explain changes. Between 
the two groups they show a clear trend from medium or small effects in favour of the control group before treatment, to small or medium effects in favour of the therapy group after treatment and at follow-up.

The evolution of all these variables demonstrates the effectiveness of the group intervention proposed here, matching or improving the results of many of the therapy groups reviewed in some reviews (Honagodu, Krishna, Sundarachar, \& Lepping, 2013; Van der Heijden, Abrahams, \& Sinclair, 2017). The group that was initially worse, after a four-month group treatment, improved or continued to improve in each of the variables studied. The control group remains stable, while the therapy group improves on all variables and maintains improvements in followup. All scores, worse at baseline in the therapy group are reversed at the end of the study to be better in this group, except for depression which is equalized after significant differences at baseline. Although only the declared stigma scores significantly on these final differences.

The main limitations of this study are the non-random assignment of participants to groups and the small final number of participants. Both limit the power of the conclusions obtained. Other variables, such as motivation for treatment, personality characteristics, important life events that occurred during the process, etc. could have played a greater role than estimated in the results obtained.

Therapy groups are an inexpensive and effective tool to help improve the emotional state of participants. In the case of HIV, the data reflect this. The limitations of this study are also present in many of the group therapeutic experiences with people with HIV. Therapy groups are run by NGOs, with people with HIV signing up or not, usually depending on their emotional support needs. If it is decided to study the experience of these groups, it is often very difficult for NGOs to find equivalent control groups with random distributions. This makes them less valuable to the scientific community. However, it represents the greatest external validity, because it responds precisely to reality. Perhaps it would be interesting for the scientific community to reconsider the current devaluation of these studies. Another factor that makes it difficult to conduct more rigorous experimental studies on the effectiveness of therapy groups is the shortage of psychologists with training and experience in group therapy, linked to the public health system assisting people with HIV.

Finally, it is important to point out that people with HIV have represented, since the beginning of the infection, a group of patients who are particularly active and linked to the search for treatment. Social and health professionals and patients learned how to respond to HIV and AIDS together. Helping to reduce their stigma and improve their emotional well-being contributes to the greater empowerment of these people, which in turn contributes to a better and more comprehensive response to the HIV epidemic.

\section{References}

Adina, J. O., Maritim, E. K., Sindabi, A. M., \& Disiye, M. A. (2017). Effect of cognitive therapy on depressive symptoms among HIV-Infected outpatiens in Kenya. International Journal of Psychology and Psychological Therapy, 17(2), 161-173. 
Aguirrezabal, A., Fuster, M. J., \& Valencia, J. (Eds.) (2009). Informe FIPSE. Integración laboral de las personas con VIH. Estudio sobre la identificación de las necesidades laborales y la actitud empresarial [FIPSE Report. Labour integration of people with HIV. Study on the identification of labour needs and business attitudes]. Madrid: FIPSE.

Amin Wani, M., \& Sankar, R. (2017). Stress, anxiety and depression among HIV/aids patients. Research Gate, 12(1), 87-97.

Beck, A. T., Steer, R. A., \& Brown, G. K. (2011). Manual. BDI-II. Inventario de Depresión de Beck-II (adaptación española: Sanz, J. y Vázquez, C.) [Manual. BDI-II. Beck Depression Inventory-II (Spanish adaptation: Sanz, J. and Vázquez, C.)]. Madrid: Pearson.

Biel, D. (2011). Análisis de la eficacia de una intervención cognitivo-conductual grupal dirigida a disminuir el impacto del estigma asociado al VIH [Analysis of the effectiveness of a cognitive-behavioural group intervention to reduce the impact of HIV-related stigma]. [Master's thesis, Autonomus University of Madrid, Spain]. http://abcpsicologia.es/reduccion-del-estigma-asociado-al-vih

Boily, M. C., Baggaley, R. F., Wang, L., Masse, B., White, R. G., Hayes, R. J., \& Alary M. (2009). Heterosexual risk of HIV-1 infection per sexual act: Systematic review and meta-analysis of observational studies. The Lancet Infectious Diseases Journal, 9(2), 118-129. doi: 10.1016/S1473-3099(09)70021-0

Carrasco, F. J., (1999). Terapia de aceptación y compromiso (ACT) en el trastorno de angustia con agorafobia: un estudio de caso [Acceptance and commitment therapy (ACT) in panic disorder with agoraphobia: a case study]. Psicothema, 11(1), 1-12.

Carrobles, J. A., Remor, E., \& Rodríguez-Alzamora, L. (2003). Afrontamiento, apoyo social percibido y distrés emocional en pacientes con infección por VIH [Coping, perceived social support and emotional distress in patients with HIV infection]. Psicothema, 15(3), 420-426.

Centers for Disease Control and Prevention. (1981). Pneumocystis pneumonia. Morbility and Mortality Weekly Report, 30, 250-252.

Division of HIV/AIDS Prevention, Centers for Disease Control and Prevention. (2020). HIV risk and prevention. Georgia, AT: Author.

Edo, M. T., \& Ballester, R. (2006). Estado emocional y conducta de enfermedad en pacientes con VIH/SIDA y enfermos oncológicos [Mood and illness behaviour in HIV/AIDS and oncology patients] Revista de Psicopatología y Psicología Clínica, 11, 79-90. doi: 10.5944/rppc.vol.11.num.2.2006.4019

Elias, B., Mendes, I., \& Mello, A. M. (2012). Quality of life of people living with HIV/AIDS and its relationship with CD4+ lymphocytes, viral load and time of diagnosis. Revista Brasileira de Epidemiología, 15(1), 75-84.

Espada, J. P., Gonzálvez, M. T., Orgilés, M. y Morales, A. (2013). Validación de la "Escala multicomponente de fobia al sida" con adolescentes españoles [Validation of the Multicomponent AIDS Phobia Scale with Spanish adolescents]. Behavioral Psychology/Psicología Conductual, 21(3), 449-460.

Feyissa, G. T., Lockwood, C., Woldie, M., \& Munn, Z. (2018). Reducing HIV-related stigma and discrimination in healthcare settings: A systematic review of guidelines, tools, standards of practice, best practices, consensus statements and systematic reviews. Journal of Multidisciplinary Healthcare, 11, 405-416. doi: 10.2147/JMDH.S170720

Fox, J., White, P. J., Weber, J., Garnett, G. P., Ward, H., \& Fidler, S. (2011). Quantifying sexual exposure to HIV within an HIV-serodiscordant relationship: development of an algorithm. AIDS, 15, 25(8), 1065-1082. doi: 10.1097/QAD.0b013e328344fe4a

Fuster, M. J. (2011). La percepción del estigma en las personas con VIH: Sus efectos y formas de afrontamiento [Perceptions of stigma among people with HIV: Its effects and ways of coping] [doctoral dissertation, National University of Distance Education, Madrid, Spain]. http://e-spacio.uned.es/fez/view/tesisuned:Psicologia-MJfuster 
Fuster, M. J., Molero, F., Gil de Montes, L., Vitoria, A., Aguirrezabal, A. y Kindelan, A. (2010). Creencias y actitudes de la población española hacia las personas con VIH [Beliefs and attitudes of the Spanish population towards people with HIV]. Madrid: FIPSE.

Fuster-RuizdeApodaca M. J., Benito, E., Poveda, A., Rohlfs, I., \& Sanpedro, E. (2018). Dimensión social del VIH y respuesta estatal [The social dimension of HIV and the state response]. Enfermedades Infecciosas y Microbiología Clínica, 36(Suppl. 1), 10-14. doi: 10.1016/S0213-005X(18)30240-4

Fuster-RuizdeApodaca, M. J., Molero, F., Biel, D., \& Barranco, C. (2013). Capacitación de las personas con VIH para afrontar el estigma y la discriminación. Manual de intervención [Empowering people living with HIV to deal with stigma and discrimination. Intervention manual]. Madrid: CESIDA.

Fuster-RuizdeApodaca, M. J., Molero, F., \& Ubillos, S. (2016). Assessment of an intervention to reduce the impact of stigma on people with HIV, enabling them to cope with it. Anales de Psicología, 32(1), 39-48.

Gaviria, A. M., Quiceno, J. M., Vinaccia, S., Martínez, L. A., \& Otalvaro, M. C. (2009). Estrategias de afrontamiento y ansiedad-depresión en pacientes diagnosticados con $\mathrm{VIH} / \mathrm{sida}$ [Coping strategies and anxiety-depression in patients diagnosed with HIV/AIDS]. Terapia Psicológica, 27(1), 5-13. doi: 10.4067/S0718-48082009000100001

Grossman, C. I., \& Stangl, A. L. (2013). Global action to reduce HIV stigma and discrimination. Journal of the International AIDS Society, $16(3$ Suppl 2), 18881 . doi: 10.7448/IAS.16.3.18881

Gueler, A., Moser, A., Calmy, A., Günthard, H. F., Bernasconi, E., Furrer, H., Fux, C. A., Battegay, M., Cavassini, M., Vernazza, P., Zwahlen, M., Egger, M., \& Swiss HIV Cohort Study, Swiss National Cohort (2017). Life expectancy in HIV-positive persons in Switzerland: Matched comparison with general population. AIDS, 31, 427-436. doi: 10.1097/QAD.0000000000001335

Hatzenbuehler, M. L., Phelan, J. C., \& Link, B. G. (2013). Stigma as a fundamental cause of population health inequalities. American Journal of Public Health, 103(5), 813-821. doi: 10.2105/AJPH.2012.301069

Honagodu, A. R., Krishna, M., Sundarachar, R., \& Lepping P. (2013). Group psychotherapies for depression in persons with HIV: A systematic review. Indian Journal of Psychiatry, 55(4), 323-330. doi: 10.4103/0019-5545.120541

Jalali, F., Hashemi, S. F., \& Hasani, A. (2018). The effectiveness of cognitive-behavioral group therapy in reducing craving among methamphetamine abusers living with HIV/AIDS. Journal of Drug Abuse, 4(2)9, 1-8. doi: 10.21767/2471-853X.100076

Jayasvasti I., Hiransuthikul, N., Pityaratstian, N., Lohsoonthorn, V., Kanchanatawan, B., \& Triruangworawat, B. (2011). The effect of cognitive behavioral therapy and changes of depressive symptoms among thai adult HIV-infected patients. World Journal of AIDS, 1 , 15-22. doi: 10.4236/wja.2011.12003

Laparra, M., Zugasti, N., Martínez-Virto, L., Damonti, P., Arza, J, Lasheras, R., Azcona, P., Adndueza, I., \& García, A. (2014). Los perfiles de la discriminación en España: Análisis de la encuesta CIS-3.000. Percepción de la discriminación en España [Profiles of discrimination in Spain: Analysis of the CIS-3000 Survey. Perception of discrimination in Spain]. Madrid: Ministerio de Sanidad, Servicios Sociales e Igualdad.

Linares-Ortiz, J., Robles-Ortega, H., \& Peralta-Ramírez, M. I., (2014). Modificación de la personalidad mediante una terapia cognitivo-conductual de afrontamiento al estrés [Personality modification through cognitive-behavioural stress coping therapy]. Anales de Psicología, 30(1), 114-122. http://dx.doi.org/10.6018/analesps.30.1.136281

Logie, C., \& Gadalla, T. M. (2009). Meta-analysis of health and demographic correlates of stigma towards people living with HIV. AIDS Care, 21(6), 742-753. doi: 10.1080/09540120802511877 
Ma, P. H. K., Chan, Z. C. Y., \& Loke A. Y., (2019) Self-stigma reduction interventions for people living with HIVIAIDS and their families: A systematic review. AIDS and Behavior, 23(3), 707-741. doi: 10.1007/s10461-018-2304-1

Mak, W. W. S., Mo, P. K. H., Ma G. Y. K. , \& Lam M. Y. Y. (2017). Meta-analysis and systematic review of studies on the effectiveness of HIV stigma reduction programs. Social Science and Medicine, 188, 30-40. doi: 10.1016/j.socscimed.2017.06.045

Ministerio de Sanidad, Consumo y Bienestar Social (2018). Vigilancia epidemiológica del VIH y sida en España 2017: sistema de información sobre nuevos diagnósticos de VIH y registro nacional de casos de sida. Área de Vigilancia de VIH y Comportamientos de Riesgo. Plan Nacional sobre el Sida - D.G. de Salud Pública, Calidad e Innovación / Centro Nacional de Epidemiología - ISCIII. Madrid: Ministerio de Sanidad, Consumo y Bienestar Social.

Muñiz, J., \& Fernández-Hermida, J. R. (2010). La opinión de los psicólogos españoles sobre el uso de los test [The opinion of Spanish psychologists on the use of the tests]. Papeles del Psicólogo, 31, 108-121.

Nobakht, A., Mohraz, M., Rahimzadeh, M., Tehranizadeh, M., Behboodi-Moghadam, Z., \& Esmaelzadeh-Saeieh, S. (2018). The effect of cognitive behavioural therapy on depression, anxiety, and stress in women with HIV. HIV and AIDS Review, 17(3), 218223. doi: 10.5114/hivar.2018.78495

ONUSIDA (2005). Violaciones de los derechos humanos, estigma y discriminación relacionados con el VIH: estudios de caso de intervenciones exitosas [HIV-related human rights violations, stigma and discrimination: Case studies of successful interventions]. ONUSIDA Colección prácticas óptimas.

Petoumenos, K., Huang, R., Hoy, J., Bloch, M., Templeton, D. J., Baker, D., Giles, M., Law, M. G., \& Cooper, D. A. (2017). Prevalence of self-reported comorbidities in HIV positive and HIV negative men who have sex with men over 55 years. The Australian Positive \& Peers Longevity Evaluation Study (APPLES). PLOS ONE, 12(9), e0184583. doi: 10.1371/journal.pone.0184583

Rabkin, J. G. (2008). HIV and depression: 2008 review and update. Current HIVIAIDS Reports, 5, 163-171. doi: 10.1007/s11904-008-0025-1

Ramiro, M. A., \& Ramírez, P. (2016). Discriminación por razón de VIH: los casos de la Clínica Legal de la Facultad de Derecho de la Universidad de Alcalá y CESIDA en 2015 [HIV discrimination: The cases of the Legal Clinic of the Law Faculty of the University of Alcalá and CESIDA in 2015.]. Revista Multidisciplinaria del Sida, 4(9), 45-54.

Remor, E., Fuster, M.J., Ballester-Arnal, R., Gómez-Martínez, S., Fumaz, C., González-García, M., Ubillos-Landa, S., Aguirrezabal-Prado, A., \& Molero, F. (2012). Development of a new instrument for the assessment of psychological predictors of well-being and quality of life in people with HIV or AIDS. AIDS and Behavior, 16, 2414-2423. doi: 10.1007/s10461-012-0230-1

Rodger, A. J., Bruun, T., Weait, M., Vernazza, P., Collins, S., Estrada, V., Lunzen, J. V., Corbelli, G. M., Lampe, F., Phillips, A., Lundgren, J., \& the PARTNER study group. (2012). Partners of people on ART-a new evaluation of the risks (the PARTNER study): Design and methods. BMC Public Health, 12, 296-302. doi: 10.1186/1471-2458-12-296

Rodger, A. J., Cambiano, V., Bruun, T., Vernazza, P., Collins, S., Corbelli, G. M., Degen, O., Estrada, V., Geretti, A.M., Beloukas, A., Phillips, A.N., Lundgren, J., \& the PARTNER Study Group. (2018, July 23-27). Risk of HIV transmission through condomless sex in MSM couples with suppressive ART: The PARTNER2 Study extended results in gay men. In P. Reiss, \& L. Bekker (Chairs), AIDS 2018 Co-chairs' choice [Symposium]. The 22 ${ }^{\text {nd }}$ International AIDS Conference (AIDS 2018), Amsterdam, Nederlands.

Rodger, A. J., Cambiano, V., Bruun, T., Vernazza, P., Collins, S., Degen, O., Corbelli, G. M., Estrada, V., Geretti, A.M., Beloukas, A., Raben, D., Coll, P., Antinori, A., Nwoñolo, N., 
Rieger, A., Prins, J. M., Blaxhult, A., Weber, R., Van Eeden, A., Brockmeyer. N. H., Clarke A., Del Romeo Guerrero, J., Raffi, F., Bogner, J. R., Wandeler, G., Gerstoft, J., Gutiérrez, F., Brinkman, K., Kitchen, M., Ostergaard, L., Leon, A., Ristola, M., Jessen, H., Stellbrink, H. J., Phillips, A. N., Lundgren, J., \& the PARTNER Study Group. (2019). Risk of HIV transmission through condomless sex in serodifferent gay couples with the HIV-positive partner taking suppressive antiretroviral therapy (PARTNER): Final results of a multicentre, prospective, observational study. Lancet, 15:393(10189), 2428-2438. doi: 10.1016/S0140-6736(19)30418-0

Rodger, A. J. Cambiano, V., Bruun, T., Vernazza, P., Collins, S., Lunzen, J., Corbelli, G. M., Estrada, V., Geretti, A. M., Beloukas, A., Asboe, D., Viciana, P., Gutierrez, F., Clotet, B., Pradier, C., Gerstoft, J., Weber, R., Westling, K., Wandeler, G., Prins, J. M., Rieger, A., Stoeckle, M., Kummerle, T., Bini, T., Ammassari, A., Gilson, R., Krznaric, I., Ristola, M., Zangerle, R., Handberg, P., Antela, A., Allan, S., Phillips, A. N., Lundgren, J., \& the PARTNER Study Group. (2016). Sexual activity without condoms and risk of HIV transmission in serodifferent couples when the HIV-positive partner is using suppressive antiretroviral therapy. JAMA, 316(2), 1-11.

Rodríguez, B., Barreales, S., \& Tuesta, R. (2018). Situación laboral de las personas con infección por el VIH en España [Employment status of people with HIV infection in Spain]. Plan Nacional sobre el Sida, Ministerio de Sanidad, Consumo y Bienestar Social.

Rueda, S., Mitra, S., Chen, S., Gogolishvili, D., Globerman, J., Chambers, L., Wilson, M., Logie, C. H., Shi, Q., Morassaei, S., \& Rourke, S. B. (2016). Examining the associations between HIV-related stigma and health outcomes in people living with HIVIAIDS: A series of meta-analyses. BMJ Open 6, 1-15. doi: 10.1136/bmjopen-2016-011453

Sanz, J., Perdigón, A. L., \& Vázquez, C. (2003). Adaptación española del Inventario para la depresión de Beck-II (BDI-II): 2. Propiedades psicométricas en población general [Spanish adaptation of the Beck Depression Inventory-II (BDI-II): 2. Psychometric properties in general population]. Clínica y Salud, 14(3), 249-280.

Spielberger, C. D., Gorsuch, R. L., \& Lushene, R. E. (1982). Manual STAl, Cuestionario de Ansiedad Estado Rasgo [STAI manual, Trait-State Anxiety Questionnaire]. Madrid: TEA.

Suárez, D., Peñate, A., \& Crespo, Y. (2009). La inteligencia emocional en personas que viven con VIH [Emotional intelligence in people living with HIV]. Duazary, 6(1), 10-25. doi: $10.21676 / 2389783 \times .688$

Stangl, A. L., Lloyd, J. K., Brady, L. M., Holland, C. E., \& Baral, S. (2013). A systematic review of interventions to reduce HIV-related stigma and discrimination from 2002 to 2013: How far have we come? Journal of the International AIDS Society, 16(3 Suppl. 2), 18734. doi: 10.7448/IAS.16.3.18734

Stockton, M. A., Giger, K., \& Nyblade, L. (2018). As coping review of the role of HIV-related stigma and discrimination in noncommunicable disease care. PLOSONE, 13(6), 1-18. doi: 10.1371/journal.pone.0199602

Stutterheim, S. E., Pryor, J. B., Bos, A. E. R., Hoogendijk, R., Muris, P., \& Schaalma, H. P. (2009). HIV-related stigma and psychological distress: The harmful effects of specific stigma manifestations in various social settings. AIDS, 23, 2353-2357. doi: 10.1097/QAD.0b013e3283320dce

Tesfaw, G., Ayano, G., Awoke, T., Assefa, D., Birhanu, Z., Miheretie, G., \& Abebe, G. (2016). Prevalence and correlates of depression and anxiety among patients with HIV on-follow up at Alert Hospital, Addis Ababa, Ethiopia. BMC Psychiatry, 16(1),368. doi: 10.1186/s12888-016-1037-9

UNAIDS. (2014a). Reduction of HIV-related stigma and discrimination. Geneva: Author.

UNAIDS. (2014b). The gap report. Geneva: Author. 
UNAIDS. (2017). Agenda for zero discrimination in health care settings. http://www.unaids.org/sites/default/files/media_asset/2017ZeroDiscriminationHealthCa re.pdf.

Vanable, P. A., Carey, M. P., Blair, D. C., \& Littlewood, R. E. (2006). Impact of HIV-related stigma on health behaviors and psychological adjustment among HIV-positive men and women. AIDS and Behavior, 10, 473-482. doi: 10.1007/s10461-006-9099-1

Van der Heijden, I., Abrahams, N., \& Sinclair, D. (2017). Psychosocial group interventions to improve psychological well-being in adults living with HIV. Cochrane Database of Systematic Reviews. doi: 10.1002/14651858.CD010806.pub2

RECEIVED: June 1, 2020

ACCEPTED: October 19, de 2020 


\section{Appendix}

\section{Content of the workshops}

\section{Workshop 1: Introduction to workshop}

\section{Session1. Friday afternoon (4 hours)}

a) Brief presentation of the therapist and the participants.

b) Brief explanation of the workshops and research.

c) Explanation and filling of questionnaires.

d) Presentation of the participants' expectations and explanation of the program.

e) Explanation of the objectives and contents of the intervention program.

f) Take turns talking to identify the difficulties of the participants.

g) Group discussion on participants' perceptions of the stated stigma:

1) Thermometer.

2) Examples of discrimination.

h) Theoretical explanation of the current situation of stigma in Spain, its origins and consequences for people with HIV (S 16-22).

i) Identification of symptoms of internalized stigma in the participants:

1) Explanation.

2) Thermometer.

3) Personal examples and group analysis of their origins and implications.

Session 2. Saturday morning (4 hours)

a) Brief theoretical discussion of the implications of hiding HIV status.

b) Group exercise aimed at analysing when and to whom you want to disclose the HIV status and training in strategies on how to do it. ${ }^{1}$

1) In the hypothetical case that you find a good reaction and welcome, who would you like to tell? Write a list. Discuss it with a partner. Group discussion.

2) Useful strategies for disclosure.

3) Role playing.

c) Group discussion on personal situations experienced with stigma and coping. Write on post-its.

d) Theoretical explanation on ways of coping with stigma from the perspective of stress management.

e) Group exercise to identify ways of dealing with the experienced stigma:

1) Write more situations of stigma and their confrontation.

2) Sort by type of coping in a panel.

\section{Session 3. Saturday afternoon (4 hours)}

a) Group discussion on self-esteem.

b) Self-esteem thermometer.

c) Theoretical presentation on self-esteem: concept and importance, characteristics of low self-esteem.

d) Self-acceptance and self-esteem exercise: I love and accept myself as I am, I love and accept you as you are.

e) Group discussion on communication and communication skills.

f) Brief theoretical explanation of communication and communication skills.

\footnotetext{
${ }^{1}$ Exercise adapted from the "Stigma toolkit" (International HIV/AIDS Alliance, 2007).
} 
g) Group exercises on effective and ineffective forms of communication for coping with stigma: Transmitting emotions with a look. Role playing: communicating serological status.

h) Theoretical explanation of emotional self-control and its usefulness in dealing with stigma.

i) Relaxation practice.

\begin{tabular}{l} 
Workshop 2. Treatment workshop I \\
\hline Session 1. Friday afternoon (4 hours) \\
a) Group discussion of experiences since the last workshop related to the contents of \\
the previous workshop, stigma and HIV. \\
b) Summary of self-esteem and characteristics of low self-esteem. \\
c) Exercise to identify personal criticism as a defining element of low self-esteem. Group \\
analysis of its origins and implications.
\end{tabular}

\section{Session 2. Saturday morning (4 hours)}

a) Theoretical explanation of communication skills: key elements in communication, elements that facilitate and hinder communication (S 13-19).

b) Group exercise: reading the fable "The oyster and the fish". Group discussion of application of what has been learned.

c) Theoretical explanation of communication skills: key verbs in communication.

d) Role-playing of communication in a situation of discrimination and/or openness about one's serological status.

e) Theoretical explanation of communication skills and communication styles: assertive communication.

Session 3. Saturday afternoon (4 hours)

a) Theoretical exposure: a quick overview of stress and how to cope with it.

b) Presentation of the $A B C$ model. Explanation of the steps for cognitive discussion of negative thoughts.

c) Example of an exercise in rejecting irrational ideas for each participant.

d) Review of tasks between sessions and closure.

Session 1. Friday afternoon (4 hours)

a) Group discussion of experiences since the last workshop related to the contents of the previous workshop, stigma and HIV.

b) Review of the tasks proposed in the last workshop. If necessary, go over them again.

c) Summary of self-esteem and characteristics of positive self-esteem.

\section{Session 2. Saturday morning (4 hours)}

a) Reading of The Warm Fuzzy Tale, reflection and debate on it.

b) Explanation of the positive recognition of the law on the economy of strokes.

c) Group exercise of positive recognition and acceptance.

d) Group exercise: boasting.

e) Review of communication skills and assertiveness.

f) Group exercise: identification of assertive, aggressive and inhibited responses.

g) Review of assertive techniques.

h) Group discussion on assertive behaviour.

i) Group exercise to identify situations of discrimination experienced and/or feared.

j) Role playing of discriminatory situations and assertive responses.

\section{Session 3. Saturday afternoon (4 hours)}

a) Exercise of sensory perception (approach to mindfulness).

b) Group discussion about the experience.

c) Role playing of discriminatory situations and assertive responses 

d) Explanation of assertive rights.
e) Individual exercise to identify when assertive rights are being asserted or not.
f) Theoretical exposure: rapid overview of stress and coping and the $A B C$ model.
g) Identification of the difficulties encountered through self-recording.
h) Review of tasks between sessions and closure.

\section{Session 1. Friday afternoon (4 hours)}

a) Group discussion of experiences since the last workshop related to the contents of the previous workshop, stigma and HIV.

b) Review of the tasks proposed in the last workshop. If necessary, go over them again.

c) Group exercise on experiences of discrimination.

d) Presentation and discussion on notions of anti-discrimination rights and HIV.

e) Group coping exercise.

\section{Session 2. Saturday morning (4 hours)}

a) Review of self-criticism and its influence on self-esteem and life achievement.

b) Group exercise: "The changer".

c) Group exercise of positive future projection.

\section{Session 3. Saturday afternoon (4 hours)}

a) Statement of the procedure for planning goals and objectives.

b) Group exercise to plan goals and objectives.

c) Completion of questionnaires

d) Review of homework assignments, group evaluation of workshop experience, farewell and closing. 